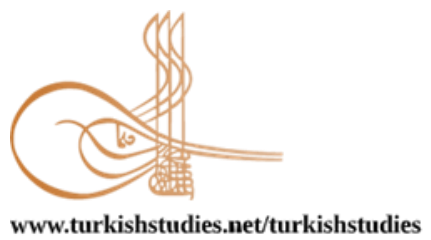

Turkish Studies

\title{
COVID-19 ile Mücadelede Sosyal Koruma Sistemleri ve İşgücü Piyasaları
}

\author{
Social Protection Systems and Labour Markets to Struggle With COVID-19
}

\author{
H. Gülçin Beken*
}

\begin{abstract}
Countries try to struggle with COVID-19 of the global pandemic by the policies which are taken both by national and international cooperation. COVID-19 affects so many fields such as production, consumption, trade, and global supply chains. Starting with the policies to protect public health have been diversified during the struggle and reached to the economic, social, and political dimension. Before COVID19 some macroeconomic indicators such as debt and employment levels have performed worse and this has affected the strategies and policies against COVID-19. There are some economies and regions in which informal employment has a high share. Recently, by the support of the International Labour Organisation (ILO), there are some implementations, strategies, and rules to be put forward for the transition from informal to formal employment. The most important one of these rules is about social protection schemes. By expanding the social protection schemes, the groups such as home-based and informal workers which can not be seen by the existing national regulations of social assistance and social protection schemes can also be covered. The importance of social protection schemes is better understood by the existence of COVID-19. At this point, the state intervention and the capacity of the state to satisfy the demand of the citizens can be seen as a new restructuring in the context of the political economy. This study tries to explain the strategies to combat COVID-19 in terms of informality and social protection.
\end{abstract}

Structured Abstract: As a global pandemic, COVID-19 challenges all the societies in terms of public health, economy, and politics. By the existence of COVID-19, it is expected to see the transformation of state-citizen relationships in the field of political economy such as the increasing role of the states. The policies and measures that are taken against COVID-19 are important to understand but the new world order in post COVID-19 period is also crucial to evaluate this change and transformation.

National policy environment differs from country to country, the responses to COVID-19 have diversified based on economy, politics, and health. Not just the governments but also several regional and international government agencies have announced emergency packages during struggle with the pandemic. A country that has strong macroeconomic indicators, extensive social safety nets, and social cohesion can perform better in the recovery process. There are some factors such as high indebtedness, low credibility which make the fight to this pandemic difficult. The economic environment after the 2008 financial crisis and strategies such as austerity policies can also affect the management of pandemic. Lockdowns and self-isolation policies were taken to stop the spread of the coronavirus but they also stress all the economic activities. All the economic activities which were stopped have important effects on the households, firms, and markets. It is also expected

\footnotetext{
* Dr.Öğr. Üyesi, Gümüşhane Üniversitesi, İ̈BF, İktisat Bölümü

Asst. Prof. Dr., Gumushane University, Faculty of Economics and Business Administration, Economics ORCID 0000-0002-1664-456X

carminomeo@ hotmail.com

Cite as/ Atıf: Beken, H. G.. (2020). COVID-19 ile mücadelede sosyal koruma sistemleri ve işgücü piyasaları. Turkish Studies, 15(6), 169-187. https://dx.doi.org/10.7827/TurkishStudies.45142

Received/Gelis: 10 July/Temmuz 2020

Accepted/Kabul: 15 October/Ekim 2020

Copyright $(\mathrm{C}$ MDE, Turkey
} 
to see the increase in absolute and relative poverty in developing countries. However, any increase in poverty makes a challenge for these countries in terms of achieving Sustainable Development Goals. Besides this, nonmonetary indicators can also be evaluated whether to see their performance for the long-term development.

If the pandemic continues to spread, it is expected to have more investment in the field of health services. However, the conditions and resources are not the same for developing and developed countries. It can be difficult for developing countries to support the fight with the pandemic considering the limited resources they have. The effects of COVID-19 on the employment and labor markets can be seen such as the level of employment, the quantity of work and on vulnerable groups. Some sectors and workers are affected badly because of their job and income losses. The jobs in essential sectors are continued but this makes the workers in a risky situation. To stay at home and to work from home can be options if the job is appropriate. In this manner, it is important to specify which job is suitable to work from home to manage the situation properly. The social protection schemes are important tools to strengthen the capacity, and capability of a person in case of facing a risky situation in the economy such as health during the life-cycle. It is a way to expand social protection schemes and implement them with universality for struggling against COVID-19. Social assistance and social insurance schemes can be integrated under social protection schemes to reach the vulnerable groups which are out of scope with the existing national schemes. By expanding social protection schemes, the informal workers can be covered and give support to the transition from informal to formal employment. It is possible to adopt both long-term and short-term objectives to struggle against COVID-19 by the measures of social protection schemes. There are some advantages to implement social safety nets and to consider social protection schemes for COVID-19 such as they can present a guarantee in the field of health and human capital in times of crisis and by the multiplier effect they can support economic recovery. It is also important to include non-governmental organizations and local authorities in the process to cover and define the vulnerable groups of society. The level of informality on the household and individual can also be taken into account. During the pandemic, the conditionality principle of social protection schemes can temporarily be removed to reach the neediest person on time. Therefore, the flexibility of the regulations is acceptable under these conditions. All the efforts and measures that have taken by the state prove the extensive governance and the importance of the relationship between the state and its citizens. COVID-19 puts all the societies in a position that affects the functioning and reshaping of global order.

Keywords: COVID-19, Social Protection Scheme, Social Assistance, Informal employment, Home-based workers.

Öz: Küresel çapta bir salgına dönüşen COVID-19 ile ulusal ve uluslararası düzeydeki iş birliği temelinde uygulanan politikalar üzerinden mücadele edilmeye çalışılmaktadır. Başta işgücü piyasaları olmak üzere, üretim, tüketim, ticaret ve küresel tedarik zincirleri gibi pek çok alan COVID-19'dan etkilenmektedir. Kamu sağlı̆̆ının korunması amacı ile başlayan politikalar COVID-19 kriziyle mücadele sürecinde çeşitlenmiş; ekonomik, sosyal ve politik düzleme de taşınmıştır. COVID-19 öncesinde dünya ekonomilerinin çoğu için bazı temel ekonomik göstergeler (borç, istihdam düzeyi) kötü bir performans göstermekte olduğundan COVID-19 ile mücadeleye yönelik politika ve stratejiler bu mevcut koşullardan etkilenmiştir. Bazı bölgelerde ve ekonomilerde enformel istihdamın payının yüksek olduğu görülmektedir. Son dönemlerde Uluslararası Çalışma Örgütü (ILO)'nün de desteğiyle, enformel ekonomiden formel ekonomiye geçiş sürecine ilişkin bazı düzenlemeler, stratejiler ve kurallar ön plana çıkmaktadır. Bu tavsiyeler içerisinde en önemlisi, ülkelerin sosyal koruma planlarına ilişkin olmaktadır. Mevcut ulusal düzenlemelerle, sosyal yardım ve desteklerin dışında kalan enformel ve ev-temelli çalışanların kapsanması; genişletilecek sosyal koruma sistemi kapsamı ile mümkün olacaktır. Bu kapsamın genişletilmesinin önemi gelir ve iş kayıplarının yaşandığı COVID-19 ile daha çok anlaşılmıştır. Bu noktada, devletlerin müdahalesi ve bu alanda gerekli düzenlemeleri yapması yönünde vatandaşlarından gelen talebe ne ölçüde cevap verebildikleri de ayrıca politik ekonomi açısından bakıldığında yeni bir yapılanma sürecinin de işareti olmaktadır. Bu çalışma, enformellik ve sosyal koruma kavramları üzerinden COVID-19 ile mücadele politikalarına yer vermeye çalışacaktır.

Anahtar Kelimeler: COVID-19, Sosyal Koruma, Sosyal Yardım, Enformel İstihdam, Ev içi çalışma 


\section{Giriş}

COVID-19'un küresel çapta bir salgına dönüşmesi ile birlikte tüm toplumları kamu sağlı̆̆g, ekonomik, sosyal ve siyasi anlamda önemli mücadele alanları ile karşı karşıya bırakmıştır. COVID19 süreciyle birlikte küresel politik ekonomi bağlamında devlet ve birey arasındaki ilişkilerin önemli dönüşümler geçirmesi, devletin rolünün artması ve vatandaşların devletten talepleri noktasında yeni baskılarla karşılaşması beklenmektedir. Alınan önlemler ve pandemiyi yönetmek için benimsenen politikalar kadar, COVID-19 sonrasında ortaya çıkacak yeni dünya düzeni üzerinden de bu değişim ve dönüşüm anlaşılmaya çalışılmalıdır.

Arz ve talep üzerindeki etkisinden, uluslararası ticarete ve işgücü piyasalarına kadar her alanda küresel düzeyde COVID-19 ile mücadeleye yönelik politikalar uygulanmaktadır. Virüsün yayılmasını önlemek ve gelebilecek diğer salgın dalgalarını yaşamamak adına alınan ilk uygulamalar ile bir sağlık krizi mücadelesi başlamış; ancak bunun bir insanlık krizine dönüşmemesi adına politika ve önlemler çeşitlendirilmek zorunda kalmıştır.

$\mathrm{Bu}$ çalışmada, genel olarak pandemi ile mücadele politikalarından bahsedilecek olup; işgücü piyasasında görünmez olan ev içi ve enformel kesimde çalışanların bu politikalardan nasıl etkilendiği açıklanmaya çalışılacaktır. Sosyal koruma sistemlerinin önemi ve gerekliliği pandemi ile mücadelede daha belirgin olmaya başladığından, sosyal koruma ve sosyal yardımlar anlamında ülkeler ve politika yapıcılar tarafindan nasıl bir yol izlenebileceği incelenecektir.

\section{COVID-19 ile Mücadeleye Genel Bakış}

COVID-19 bireyler, şirketler ve devletler üzerinde hem iş yapma ve karar alma biçimleri hem de karşılaşılan riskler üzerinden etkili olmaktadır. Pandemi süreci devletleri önemli kararlar almak zorunda bırakmıştır. Hangi önlemlerin alınacağı, hangi kısıtlamaların getirileceği, alınan kararların esnetilip esnetilemeyeceği, paranın öncelikli olarak hangi alanlara harcanacağı kadar; ulusal bağlamda alınan kararların uluslararası iş birliğini olumsuz etkilememesi için neler yapılabileceği de incelenmesi gereken konular arasındadır (Frieden, 2020:5). Ulusal politik ekonomi koşulları ülkeden ülkeye farklılık gösterdiğinden COVID-19'a verilen cevapların da ekonomi, politika ve sağl1k düzleminde çeşitlendiği görülmektedir.

Ulusal düzeyde devletlerin ötesinde çeşitli uluslararası, bölgesel kalkınma bankaları ve uluslararası kalkınma iş birliği örgütleri de pandemi ile mücadele sürecinde finansal paketler açıklamıştır. 7 Mayıs itibarıyla bu kurumların 1.35 trilyon dolarlık yardımı acil destek paketleri, kredi tesisleri, borç servisi yardımları ve hibeler şeklinde, krizin ortaya çıkardığı sağlık sorunları ile mücadelede, salgının sosyoekonomik etkilerini hafifletmek amacıyla verdiği görülmüştür (ILO 2020a:11). 
Tablo 1: COVID-19 ile Mücadelede Uygulanan Politika Örnekleri

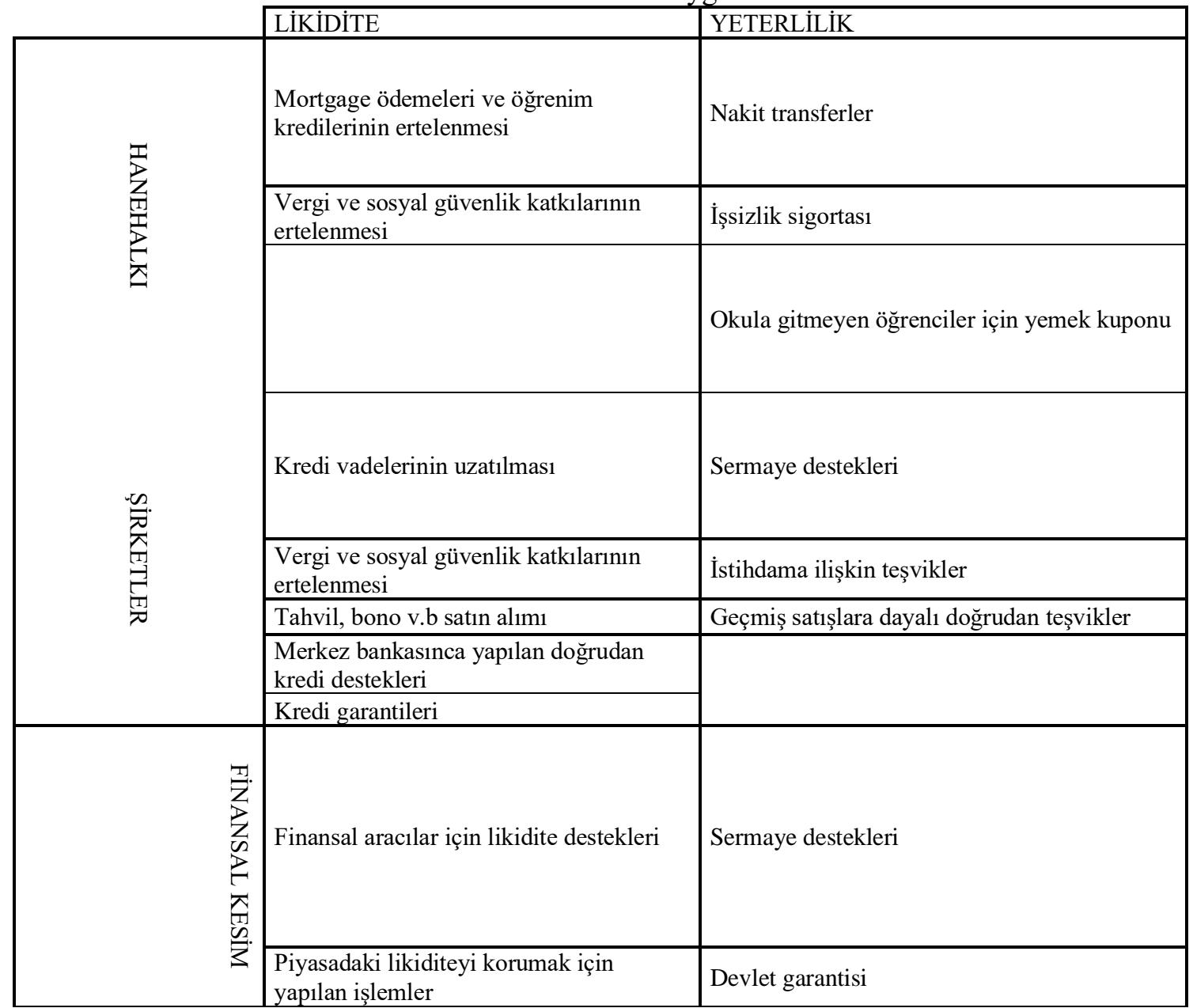

\section{Kaynak: Dell'Ariccia vd.(2020)}

COVID-19 ile mücadelenin iki aşamalı olduğu söylenebilir. İlk aşama, COVID-19 ile savaşı ve ikinci aşama da COVID-19 ile savaş sonrasındaki yeniden yapılanmayı ifade eder. İlk aşamada temel endüstrilerin işleyişini sağlamak, krizden etkilenenlere yeterli kaynakları sunabilmek ve ekonomik bozulmanın düzeyini düşük tutma yönündeki politikalardan bahsetmek mümkündür. Ülkeler tarafından hanehalkları, şirketler ve finansal sektöre yönelik Tablo 1 ile gösterilebilecek politika örnekleri hem ayrı ayrı hem de birlikte uygulanabileceği gibi uluslararası iş birlikleri ile de desteklenebilir (Dell’Ariccia vd., 2020). Bu bağlamda Avrupa Birliği düzeyinde alınan politika önlemleri; a) harcama (yüksek sağlık harcamaları, kısa dönem çalışma ödeneği), b) vergi (vergi erteleme), c) sektörel-bölgesel ya da mali önlemlerden başkası ve d) diğer önlemler (makro ihtiyati önlemler, bankacılık sektörüne verilen destekler, merkez bankasınca alınan kararlar) şeklinde sinıflandırılabilir ${ }^{1}$ (European Commisssion, 2020).

Şu an virüsle mücadele kavramı öne çıksa da virüsle savaş döneminde önemli olan bir nokta da dünyadaki pek çok ülkenin bu krize yüksek borç oranları ile yakalanmış olduğu gerçeğidir (Dabla-

\footnotetext{
${ }^{1}$ ABD örneğine bakıldığında 27 Mart 2020 ile CARES doğrudan ekonomik desteği; işçilere, ailelere, küçük işletmelere ve ABD endüstrilerine verilen 2 trilyon dolarlık bir ekonomik yardım programı olarak, kamu sağlığını korumak ve salgının olumsuz ekonomik etkilerini azaltmak amaciyla uygulamaya konulmuştur. (https://home.treasury.gov/policy-issues/cares) Ancak uygulanma şekline bakıldığında finansal anlamda kırılgan olanlar CARES'teki desteklere başvurma isteğinde olsalar da uygunluk kriterlerini yerine getirme zorunluluğu ve bürokratik engellerle karşılaşmaktadır (Bartik vd., 2020:2).
} 
Norris ve Zdzienicka, 2020:37). Bunu destekler şekilde, Köse vd. (2020a) çalışması, gelişmekte olan ve yükselen piyasaların 1970-1989 (ilk dalga), 1990-2001(ikinci dalga), 2002-2009 (üçüncü dalga) ve 2010 ile dördüncü dalga borç birikimi kaynaklı krizler yaşadığını göstermektedir. Bu gruptaki ülkeler için geniş çaplı ve ciddi boyutta bir finansal baskı, COVID-19 sonrasında ortaya çıkmıştır. Kırılganlıklarını artıran diğer destekleyici faktörler daha riskli borçlanma eğilimleri, mali ve cari işlem açıkları olmuştur. (Köse vd., 2020b: 42) Dolayısıyla, pandemi ile mücadelede ülkeleri etkileyen en önemli faktörlerden biri, ekonomik anlamda bu krize yakalandıkları başlangıç koşullarının düzeyidir. Güçlü makroekonomik göstergeleri, sosyal güvence ağları olan ve sosyal uyuma sahip ülkelerin daha hızlı ve sağlam şekilde iyileşme sürecini gerçekleştirdikleri görülmektedir. Yüksek borçluluk, düşük kredibilite gibi mevcut kırılganlıklar hem hanehalkları hem şirketler hem de ülkeler açısından iyileşmeyi zorlayan faktörler olarak ortaya çıkmaktadır (Georgieva, 2020:11).

Tablo 2: Genel Mali Denge ve Brüt Borç Düzeyi (\%GSYH)

\begin{tabular}{|l|l|l|l|l|l|l|l|l|}
\hline & \multicolumn{3}{|l}{ Genel mali denge (\%GSYH) } & \multicolumn{3}{l|}{ Brüt borç(\%GSYH) } \\
\hline & 2018 & 2019 & $2020^{*}$ & $2021^{*}$ & 2018 & 2019 & $2020^{*}$ & $2021^{*}$ \\
\hline Dünya & -3.1 & -3.9 & -13.9 & -8.2 & 81.2 & 82.8 & 101.5 & 103.2 \\
\hline Gelişmiş ekonomiler & -2.7 & -3.3 & -16.6 & -8.3 & 104 & 105.2 & 131.2 & 132.3 \\
\hline Yükselen ekonomiler & -3.8 & -4.9 & -10.6 & -8.5 & 48.9 & 52.4 & 63.1 & 66.7 \\
\hline Düşük gelirli GOÜ & -3.8 & -4.1 & -6.1 & -5.1 & 42.9 & 43.1 & 48.2 & 49 \\
\hline
\end{tabular}

*yapılan tahminleri yansitır.

Kaynak:IMF,(2020a),https://www.imf.org/en/Publications/WEO/Issues/2020/06/24/WEOUpdateJun e2020.

2008 küresel krizinden sonra devralınan ortamın, kemer sıkma politikaları gibi krizden çıkma stratejilerinin uygulandığı bir dönemin, pandemi sürecinin yönetimine olan etkisi de unutulmamalıdır. Büyüyen özel/kamu borcu, gelir ve servet eşitsizliği ortamında para ve maliye politikaları da yeteri kadar başarılı sonuçlar ortaya çıkaramamaktadır. COVID-19 ile mücadele ekonomileri durgunluk tehlikesi ile karşılaştırdığ 1 gibi bahsedilen mevcut sorunların üstesinden başarı ile gelebilme olanağını da zayıflatmaktadır (Florini ve Sharma, 2020: 49).

Tablo 3: Dünya Ekonomisine Genel Bakış Projeksiyonlar (\%)

\begin{tabular}{|l|r|r|r|r|}
\hline & 2018 & 2019 & $2020\left(^{*}\right)$ & $2021\left(^{*}\right)$ \\
\hline Dünya çıtı düzeyi & 3.6 & 2.9 & -4.9 & 5.4 \\
Gelişmiş ekonomiler & 2.2 & 1.7 & -8.0 & 4.8 \\
Yükselen ve gelişmekte olan ülkeler & 4.5 & 3.7 & -3.0 & 5.9 \\
Dünya Ticaret Hacmi & 3.8 & 0.9 & -11.9 & 8.0 \\
\hline
\end{tabular}

*tahmini

Kaynak:IMF(2020a),https://www.imf.org/en/Publications/WEO/Issues/2020/06/24/WEOUpdateJune2020.

Bu sene için IMF'nin küresel çıktının gerçekleşeceği düzeye ilişkin öngörüsü \%-4.9 olarak belirlenmiştir. Gelişmiş ülke grupları için küçülme oranının yükselen ve gelişmekte olan ülke gruplarına kıyasla daha da yüksek olduğu bu projeksiyonlarda görülmektedir (IMF, 2020a). COVID19 ile mücadele kapsamında alınan önlemlerin küresel ya da ulusal düzeyde ekonomik büyüme açısından olumsuz sonuçları (kamu gelirinde azalma, vergi gelirleri ve sosyal güvenlik katkıları) olabilecektir. Bu nedenle COVID-19 öncelikli olarak uzun dönemde sosyal korumanın finanse edilmesini zorlaştıracağından, bu programların ve sistemlerin uzun vadedeki sürdürülebilirliğini sıkıntıya sokması mümkündür (IPC-IG/GIZ/BMZ/DFAT, 2020).

Karantina ya da tamamıyla sokağa çıkma yasakları gibi önlemler virüsün yayılmasını engellemek adına alınmakla birlikte ekonomik faaliyetleri de baskı altına almaktadır. Gerçekleştirilemeyen bu ekonomik faaliyetlerin bireyler ve hanehalkları için önemli dağılımsal etkileri ortaya çıkmaktadır. Virüsün yavaş yayılımı sağlık risklerini yaşlılar için azaltırken, ekonomik 
aktivitelerin azalması ve düşük istihdam düzeyinin yükü gençler tarafından taşınmaktadır. $\mathrm{Bu}$ nedenle, karantina politikaları önemli çapta geliri yeniden dağıtıcı kamu politikalarının uygulanmasına (gençler ve yaşlılar, hasta ve sağlıklı olanlar, farklı sektörlerde çalışanlar) ihtiyaç doğurur (Glover vd., 2020:2). Bu durum, virüsün ortaya çıkardığı zararların hanehalkı içerisindeki eşitsizliği arttırdığının ve virüsle mücadeleye yönelik maliyetleri her bir birey için farklılaştırdığının bir ifadesidir.

McKibbin ve Fernando (2020) salgının devam etmesi halinde, ortaya çıkacak maliyetlerin tüm ekonomilerde kamusal sağlık hizmetlerine daha fazla yatırım yapılması ile artacağını, özellikle de sağlık sistemlerinin daha az geliştiği ve nüfus yoğunluğunun yüksek olduğu daha az gelişmiş ülkelerde gerekli yatırımların yapılması ile salgının olumsuz etkilerinden kaçınılabileceğini vurgulamaktadır.

Sumner vd. (2020)'nin, dünya ekonomisinde $\% 5, \% 10$ ve $\% 20$ düzeyinde gerçekleşecek bir daralmanın çeşitli yoksulluk çizgilerine göre yoksulluk üzerindeki etkilerine baktıkları çalışmada, pandeminin ekonomik sonucu olarak GOÜ'lerde mutlak ve göreceli yoksulluğun artacağını (yaklaşık yarım milyon insan) ve bunun Birleşmiş Milletler Sürdürülebilir Kalkınma Hedefleri açısından bir meydan okuma yaratacağını vurgulamaktadır. Gözden kaçırılmaması gereken bir diğer nokta da parasal olmayan göstergelerin bu ülkelerde nasıl bir trend izleyeceğidir. Bu etkilerin boyutu, pandeminin ne kadar süreceğine, ulusal ve uluslararası toplumda ne tepkiler verileceğine bağlı olarak değişecektir.

\section{2.İssücü Piyasalarına Bakış}

COVID-19'un yayılmasını önlemek amacıyla ulusal ve uluslararası düzeyde benimsenen politikalar, ticaret, istihdam, üretim, tüketim v.b. pek çok alan üzerinde etkili olmuştur. Küresel ölçekte küçülmenin, bazı sektörlerde daralmaların, istihdam ve gelir kayıplarının beklendiği bu sürecin bireylere, hanelere ve firmalara olan etkisi pandeminin yayılma hızı ve ölçeğine bağlı olacaktır. En çok etkilenmesi beklenen işgücü piyasalarının performansıdır. COVID-19 ile mücadele ederken alınan politikaların ve kullanılan araçların işgücü piyasası göstergeleri üzerinde önemli, doğrudan ve dolaylı etkileri ile karşılaşılmaktadır.

COVID-19'un küresel düzeyde işgücü piyasası ve çalışmaya olan etkisinin üç alanda görülmesi beklenmektedir: a) işlerin miktarı (işsizlik ve eksik istihdam), b) işin kalitesi (ücretler ve sosyal koruma) ve c) işgücü piyasasındaki olumsuz koşullara daha kırılgan olan belirli gruplar üzerindeki etkisi. Bu nedenle COVID-19 ile mücadele politikalarının iki acil hedefe odaklanmas1 gereklidir: Sağlığın korunmasına (iş yerlerinde alınacak koruyucu önlemler gibi) yönelik önlemler ile arz ve talebe yönelik ekonomik desteklerin (istihdam ve gelir destekleri, arz ve talep şoklarını engellemek ve resesyonun uzamasının önüne geçmek) sunulması (ILO,2020b:3).

\subsection{Enformel İstihdam ve Ev Temelli Çalışma}

İşü̈cü piyasası ve çalışanlar açısından COVID-19'un olumsuz etkilerinden bahsetmekle birlikte, hangi çalışan grubu için bu durumun konuşulduğu da önemlidir. Yaşanan iş kayıpları değerlendirildiğinde işlerin türlerine göre farklılaşan etkilerden bahsedilmelidir. Sosyal mesafe ve sokağa çıkma yasakları uygulansa da pek çok ülkede (sağlık hizmeti verenler, market çalışanları v.b.) temel sanayilerdeki faaliyetlerin sürdürülmesi sağlanmıştır. Tersine, turizm ve eğlence gibi fiziki etkileşim gerektiren bazı endüstrilerdeki işler ise kesintiye uğramıştır (Shibata, 2020:4).

CISA (2020)'nın tavsiye niteliğindeki raporunda "temel" olarak adlandırılan endüstriler; sağlık ve tıbbi bakım, telekomünikasyon, bilgi teknolojileri, savunma, gıda ve tarım, ulaşım ve lojistik, enerji, su ve atık su v.b olarak belirtilmiştir. Altyapıyı ilgilendiren ve sürdürülmesini destekleyen her türlü hizmet ve faaliyet bu kapsamda değerlendirildiğinden, bu alanlarda çalışan işçilerin korunması ve COVID-19 nedeniyle diğer işçilere göre karşılaştıkları daha yüksek riskleri yönetebilmek önemli bir sorun olarak görülmektedir. 
Temel endüstrilerin ürün ve hizmetlerine yönelik talep artış1 olsa da bu endüstrilerde çalışanlar genellikle ekonomik olarak dezavantajlı kesimleri temsil etmektedir. Temel endüstriler ve bu endüstrilerde çalışanlar açısından tüm ekonomik ve sosyal koşulların eşit olduğu söylenemez. Örneğin, ABD işgücü piyasasında bu sektörlerde çalışanlardan bazıları oldukça rekabetçi ücretler alırken, diğerleri ulusal medyan gelirin bile altında ücret almaktadır- COVID-19 bu gruplar için gelir düzeyine, sağlık desteklerine ve yaşam sigortalarının olup-olmamasına göre farklı sonuçlar doğurmaktadır (Tomer ve Kane, 2020). Bunu destekler şekilde, Mongey vd. (2020:15) de pandemiden en çok etkilenen grubun ABD ekonomisi içerisinde daha çok ekonomik anlamda kırılgan olanlar olduğunu belirtmiş, görece daha az eğitimli, sağlık hizmetlerine ${ }^{2}$ erişimi sınırlı olan ve gelir dağılımının en alt diliminde yer alanların bu grubu oluşturduğunu vurgulamıştır.

COVID-19 ile gündeme gelen konulardan biri de mevcut koşullar altında evden çalışmayı ve sosyal mesafenin korunmasını gerekli kılmasıdır. Hangi işlerin evden yürütülebileceğinin doğru belirlenmesi sosyal sigorta ödemelerinin en çok ihtiyacı olanlara yapılabilmesi açısından önemlidir. Sosyal mesafe ve bunu izleyen dönemde ekonominin sergileyeceği performansı görebilmek adına evden yürütülebilecek işlerin oranını ölçebilmek önemli bir avantaj sağlayacaktır (Dingel ve Neiman, 2020:11).

Evden çalışma yaygınlaşsa ve tercih edilse de her işin evden çalışmaya uygun olup olmadığ tartışmalıdır. Hatayama vd. (2020a:18)'nin, 53 ülke verisini kullanarak yaptıkları çalışmada fakir ülkelerde, erkek ve düşük eğitimli, serbest çalışan ve enformel işlere sahip olan işçilerin sosyal mesafe politikalarına karşı daha kırılgan ve işlerinin doğası gereği evden çalışmanın onlara daha az uygun olduğu bulunmuştur. Dolayısıyla, bu sonuçlar enformel sektörde yer alanlar için gelir korumaya yönelik politikaların önemini ve bu gruptakilerin formel mekanizmalar aracıllğıyla şekillendirilen sosyal koruma programlarına erişim düzeyinin daha düşük olduğunu göstermiştir.

Berg vd. (2020)'ye göre, gelişmiş ülkeler gelişmekte olanlara kıyasla evden çalışmaya daha uygun yapıdadır. Gelişmekte olan ülkelerdeki çoğu çalışan, evden yapılamayacak türdeki mesleklere sahip olduğu gibi bu mesleklerin de o toplumlarda daha yaygın olduğu görülmektedir. İşin yapısı ve bilgi teknolojilerinin altyapı hizmetlerine uygulanma kapasitesi her iki ülke grubu için farklılık göstermektedir. Küresel düzeyde her altı işçiden birinin ve gelişmiş ülkelerde dört işçiden birinin potansiyel olarak evden çalışabilmesi mümkündür. Bu durumda, sosyal mesafeye ilişkin alınan önlemlerin, ülkeler arasındaki ve içerisindeki mevcut ekonomik eşitsizlikleri genişleteceği ve derinleştirebileceği söylenebilir (Hatayama v.d, 2020b).

Uluslararası Çalışma Örgütü (ILO), "Evde Çalışma Sözleşmesi"nde, evde çalışanlar ile diğer ücret kazananlar arasında eşit muamelenin (sosyal güvenlik, ücret, iş güvenliği, sosyal koruma v.b.) sağlanması gerektiğini vurgulamaktadır. Pandemi dolayısıyla ortaya çıkacak sorunlardan biri de pandemi kontrolü nedeniyle evden çalışmaya yönlendirilen ve başlayanların durumunun hangi kapsamda değerlendirileceği noktası olmaktadır (WIEGO, 2020a).

Evde çalışanlar (kendi işinin sahibi olarak ya da taşeron usulü ev tabanlı çalışanlar) genellikle düşük ücretlerle, geciken ödemelerle, düzensiz ve/veya ertelenen siparişler ile karşı karşıyadır. Bu genel olumsuzluklara bir de pandeminin yarattığı belirsizlik ve risklerin eklenmesi, bu grup çalışanları gelir kaynağı noktasında sıkıntıya sokmaktadır. Gelişmekte olan ülkelerde ev tabanlı çalışma genellikle daha farklı tanımlanmakta ve belli bir iş yerine gitmeden daha çok evden

\footnotetext{
${ }^{2}$ ABD, parçalı sağlı sistemine sahip bir ülke olduğundan, COVID-19'un dünya ekonomisinde yaratacağı resesyon ve insanların ceplerinden bu öngörülemeyen sağlık harcamalarını karşılamak zorunda kalması ABD ekonomisi için büyük bir maliyet unsuru oluşturacaktır. Kaç kişinin enfekte olacağı ve ciddi şekilde hastalanacağına bağlı olarak işverenler, sigortalananlar ve sağlık sistemi açısından ilave maliyetlerle karşılaşılabilecektir. Özel sigortası olan ve ciddi hastalığ olan bir bireyin cebinden yapacağı harcamanın 1.300\$’a ulaşabilmesi beklenmektedir (Rae vd., 2020).
} 
çalışanları ifade etmektedir. Bazıları için esnekliğin sağladığı faydalarla ilişkili iken, diğerleri için düşük kaliteli çalışma koşulları ya da kendileri adına çalışabilme firsatıdır (WIEGO, 2020a).

Küreselleşme sürecinde, küresel ölçekteki ticaret ve yatırımların çalışanlar üzerinde özellikle de kadınların istihdamı ve geliri üzerinde negatif ya da pozitif etkisi (ülkeye, sektöre göre farklılaşarak) ile karşılaşmak mümkündür. Enformel sektörde çalışan kadınlar düşünüldügünde, büyük ölçekli firmalar ulus ötesi hareketliliğe sahipken, emek görece hareketsiz olabildiğinden, küresel tedarik zinciri içerisinde üretim ve dağıtım süreçlerinin yeniden yapılanması yönünde ortaya çıkan etkiler, COVID-19 ile yeniden şekillenmektedir. Küresel rekabet ve bütünleşmenin özellikle ev içinde çalışanlar için olumsuz sonuçlar çıkarmasının arka planında, sermayenin ulus ötesi hareketliliğinin firmalara ulusal emek standartlarını ve toplu pazarlıkları aşındırma gücü vermesi gelmektedir (Carr vd., 2000:138).

Küresel tedarik zincirinin bir parçasını oluşturan ev-temelli çalışma, pandemi nedeniyle siparişlerin ertelenmesi ya da iptal edilmesine dayalı sorunlar yaşamaktadır. Gelir kaybı kadar, ev temelli çalışanların ülkelerin düzenledikleri acil yardım paketlerinde enformel ve formel çalışanlar gibi kapsanmaması da onları paketlerin dışında bırakmaktadır. Genellikle, altyapı donanımı olarak zayıf, küçük ve kalabalık bu evlerde, COVID-19 ile gelen yeni kısıtlamaları yerine getirebilmek özellikle sağlık ve sterilizasyon anlamında mümkün olamayacaktır. Kadınların ağırlıklı olduğu bu ev temelli çalışma, pandemi nedeniyle kreşlerin ve okulların kapalı olduğu bir ortamda onları diğer ev işleri, çocuk bakımı v.b. sorumluluklar noktasında da zorlamaktadır (WIEGO, 2020b; Minter, 2020). Genellikle, görünmez olan bu çalışan grubunun sosyo-ekonomik durumu ve koşullarının pandemiden korunmasına yönelik özel program ve destekler uygulanmasına ihtiyaç duyulmaktadır.

ILO (2020c)'ye göre ev hizmetinde çalışanların \%76's1 Güneydoğu Asya'da, \%74'ü Amerika'da, \%72'si Afrika'da ve \%45'i Avrupa'da pandemi kaynaklı risk altındadır. Enformel ya da formel, pandemi tüm ev işçilerini etkilese de enformel kesim içerisinde kalanların \%76'sı işini ya da çalışma saatini kaybetme riski ile yüzleşmektedir. Ev işçilerinin sadece \%10'u sosyal güvenliğe erişebilmektedir; ücretli hastalık izni, sağlık hizmetine erişim, iş kazası güvencesi ya da işsizlik ödeneği de alamamaktadır. Dünya genelinde ev içi hizmette çalışanların 3/4'ü yani yaklaşık 55 milyondan fazlası, gelirini ve işini sokağa çıkma yasağı ve etkin sosyal güvenlik sistemi kapsamı olmaması dolayısıyla kaybetme riski altındadır.

Avrupa Birliği'nde hangi sektörlerin ve işlerin COVID-19'a daha kırılgan olduğuna yönelik Sanchez vd.(2020) çalışması, genç, eğitim düzeyi düşük ve göçmenlerin bulunduğu düşük ücretle ve daha az güvence altında çalışanların olduğu geride kalmış bölgelerde iş kayıplarının olduğunu ortaya koymaktadır. Ekonomik olarak dezavantajlı bölgeler, COVID-19 tarafindan işgücü piyasası en çok olumsuz etkilenen alanlardır. En düşük gelir payına sahip işçiler en yüksek kırılganlığı taşımaktadır. Evden çalışamayan işçiler, temel sektörler dışında çalışanlar ve/veya yoğun şekilde yüzyüze etkileşim gerektiren işlerde çalışanların gelirlerinde keskin düşüşler yaşanmıştır. Bulunan sonuçlara göre, en alt onda birlik gelir diliminde yer alan işçiler en yüksek gelir dilimindekilere göre iki kat daha fazla iş kaybetme riski taşımaktadır.

Avrupa Birliği düşünüldüğünde "geride kalan bölgeler", düşük gelirli (Orta ve Doğu Avrupa) ve düşük büyüme oranlarına sahip (Güney Avrupa) bölgelerin ifadesidir. Bu geride kalan bölgelerin ortak özelliği, düşük iş gücüne katılım oranı, tamamlanmayan yapısal reformlar, beceri düzeyi ve kurumsallaşma konusundaki eksikliklerdir. Bu bölgeler, iş gücü piyasası göstergeleri açısından zayıf performans göstermektedir. Temel sorun, genel olarak istihdam oranlarının ve kadınların iş gücüne katılım oranının düşük olmasıdır (Farole vd., 2020). Yapısal anlamda var olan bu sorunların, COVID-19 etkisi ile daha da ağırlaşabilecek olması yakın dönemde öncelikli çözüm bulunması gereken alanlardan birini oluşturmaktadır.

Saltiel (2020), gelişmekte olan ülkelere yönelik yaptığı çalışmada, evden çalışmanın uygunluğunun, yüksek ücretli mesleklerle pozitif ilişkili olduğunu göstermektedir. Eğitim düzeyi, 
formel istihdam, hanehalkı serveti v.b. evden çalışabilme olasılığ ile pozitif ilişkilidir. Gottlieb vd.(2020)'ye göre, gelişmekte olan ülkelerde (\%20) gelişmiş ülkelere (\%40) kıyasla, özellikle kentsel alanlardaki iş yapma biçimleri evden çalışmaya daha az uygundur. GOÜ'lerde istihdamın büyük çoğunluğu kendi adına çalışan işçilerdir. İstihdamdaki payları büyük olmakla birlikte, yaptıkları işler evden çalışmaya uygun değildir.

ILO (2020d) çalışması küresel ölçekte ev içi hizmetlerde çalışanlardan \%49.3'ünün pandemiden önemli ölçüde etkilendiğini tahmin ederken, bu oran 15 Mayıs tarihinde \%73.7'ye çıkmış ve 4 Haziran itibarıyla \%72.3 düzeyine gerilemiştir. COVID-19'un ev içi hizmette çalışanlar için en önemli sonucu çalışma saatlerindeki azalma ve bazı durumlarda da iş kaybı olmuştur. "Önemli ölçüde etkilenmiş" ile ifade edilen çalışma saatlerindeki azalma, kazançlarda kayıp ve iş kayıplarının yaşanması halidir. Ev tabanlı çalışan işçiler, kendi işinin sahibi olabileceği gibi parça başına anlaşarak alt sözleşmelerle kendi evlerinde ya da çevrelerinde de çalışabilir. Evde çalışanlar ve kendi adına çalışanların ortak noktası işlerin düzensizliği, düşük gelirler, kötü çalışma ve yaşam koşulları ve kamu/özel destek hizmetlerine erişimlerinin olmamasıdır (ILO, 2015a:1-3).

1 Nisan 2020 ile ILO, çalışma saatlerinin ikinci çeyrekte küresel ölçekte \% 6.7 azalmasını beklemektedir. Sektörel bazda, COVID-19'un ekonomik etkisine bakıldığında, imalat, toptan ve perakende, gayrimenkul, konaklama ve yiyecek sektörlerinde yüksek düzeyde çıtı kaybı yaratması beklenmektedir. Bu sektörler, emek-yoğun, düşük ücret ve düşük beceri düzeyi ile çalışanların olduğu alanlardır. Ekonomik risklerin bu sektörlerde çalışanlar için yüksek olması beklenmektedir (ILO, 2020e). Bu bağlamda, COVID-19'un etkileri işgücü piyasasının nasıl yapılandığına (enformel istihdamın varlığı ve payı gibi) bağlı olarak ülkeler düzeyinde farklılaşacağından ulusal düzeydeki politika önerileri de çeşitlenecektir.

\subsection{Sosyal Koruma Sistemleri, Enformellik ve COVID-19 Politikaları}

Sosyal koruma programları bir toplumun üyelerinin temel ekonomik ve sosyal güvenceye sahip olmasını ve yaşam boyu karşılaşılabilecek risklere (yaşl11ık, hastalık, işsizlik v.b.) karşı koruma altına alınmasını sağlayan araçlardandır. Sosyal koruma programları maliyeti, finansal yükü ve işgücü piysalarında bireylerin kamusal desteklere olan bağımlılı̆̆ arttırabilmesi nedeniyle eleştirilmektedir (Garcia ve Gruat, 2003). Sosyal koruma sistemleri, kapsayıcı büyümeye ve insani gelişmeye olan katkısı, toplumsal barış ve politik istikrar oluşturması ve insanları şoklara karşı koruyacak yeterliliklere kavuşturması nedeniyle benimsenen bir strateji olmaktadır (Ortiz, 2018:32). COVID-19 ya da daha önce yaşanan pandemiler pek çok insanın beşerî sermaye açısından gelişimini olumsuz etkileyebilecek koşullar ortaya çıkarmaktadır (Garcia ve Garut, 2003). Bu nedenle, COVID19 gibi ani bir küresel salgının getirdiği ekonomik, sosyal ve sağlık riskleri karşısında bireylerin dayanma gücünü, kapasitesini ve yapabilirliklerini artıran bir araç olarak sosyal koruma sistemlerinin benimsenmesi ve evrensellik temelinde uygulanması pandemi ile mücadelede kullanılan yöntemlerden biridir.

Evrensel sosyal koruma sistemleri oluşturmak, toplumdaki tüm bireylerin yaşam döngüsü içinde karşılaşabilecekleri risklere karşı korunmasını sağlarken, aynı zamanda bireysel, sosyal ve ekonomik kalkınmaya da katkıda bulunur. Özellikle, sosyal yardımlar, sosyal sigorta ve işgücü piyasasına (hem formel hem de enformel) yönelik araçlar gibi farklı alanlara ilişkin düzenlemelerin bütünleştirilmesi ile toplumdaki tüm bireylere kapsamlı ve uzun vadeli bir sosyal korumanın sağlanması temel amaçtır (Ulrichs ve White-Kaba, 2019:2).

Enformel ekonomi için farklı tanımlar yapılabilse de ILO tarafindan genellikle, "yasalarda ya da uygulamalarda iş̧̧iler ya da ekonomik birimler tarafindan gerçekleştirilen ancak formel düzenlemelerle kapsanmayan ya da yeteri kadar kapsanmayan tüm faaliyetleri içermektedir" şeklinde tanımlamaktadır. ILO enformel ekonomiden formel ekonomiye geçiş süreci için tavsiyelerde bulunmakta ve özellikle düzgün iş kavramı bağlamında sosyal korumanın genişletilmesini (sosyal koruma tabanlarının ve sosyal güvenlik sistemlerinin oluşturulması) bu 
sürecin bir aracı olarak vurgulamaktadır. Enformel ekonomiden formele geçişe öncelik verilmesinin nedeni, enformel ekonomi içerisinde istihdam edilenlerin yaşam standardının düşük olması, bu bireyleri yoksulluk ve enformellik tuzağından çıkarabilecek firsatların desteğinden uzakta tutmasıdır (ILO, 2014; ILO, 2015b).

15 yaş ve üzeri enformel çalışan 2 milyarlık dünya nüfusu, küresel istihdamın $\% 61.2$ 'sini temsil etmektedir. Küresel ölçekte kadınların \%58.1'i ve erkeklerin \%63'ü enformel istihdam içerisindedir. Enformel istihdamın COVID-19 öncesi küresel bağlamdaki oranları oldukça yüksekken, sahip oldukları dezavantajlı koşullar da düşünüldüğünde COVID-19'un bu kesimi daha ciddi bir şekilde etkilemesi beklenmektedir. Sosyo-ekonomik gelişim düzeyi ile formellik arasında pozitif bir ilişki bulunduğu düşünülecek olursa, COVID-19 süreci bu ülkelerin sosyo-ekonomik anlamda kalkınma düzeyinde yaşayabilecekleri olumsuzlukları da ortaya çıkarmaktadır. Gelişmekte olan ve yükselmekte olan ülkelerin enformel istihdamdaki payları (dünya istihdamının \%82'sini temsil ederlerken, dünyadaki enformel istihdamın \%93'ü bu ülkelere aittir), gelişmiş ülkelerdekinden daha yüksektir. (ILO,2018:8) Kısa vadede COVID-19'un yayılmasını engellemek politika tercihlerinde öncelikli olsa da uzun vadede ülkeler açısından özellikle kalkınma performansları ve fırsatları açısından yaşanabilecek kayıpların gözardı edilmemesi gereklidir.

COVID-19 enformel çalıșanlar açısından değerlendirildiğinde, ev içi çalışanlar, ev içi hizmette (ev tabanlı) çalışanlar, sokak satıcıları ve atık madde toplayıcıları en kırılgan grupları oluşturmaktadır. Talepteki düşüş, çocuk bakım sorumluluklarındaki artışlar, piyasaya erişimin olmaması, kamusal alanlarda çalışmanın yasaklanması v.b. bu kesimlerin gelirlerini etkilemektedir. Uzun dönem etkiler, enformel iş̧̧i örgütlerinin elde ettiği gelirlerin de sıkıntıda olması nedeniyle artabilir (Alfers vd., 2020). Özellikle enformel istihdam içerisinde çalışan kadınların COVID-19 önlemlerinden olumsuz etkilenmemesi için üç noktaya dikkat edilmelidir: Sosyal korumaya erişimin genişletilmesi, temel sektörlerdeki enformel işçilerin haklarının ve güvenliğinin sağlanması, enformel işçileri temsil eden örgütlerin ve sendikaların desteklenmesi (Moussié ve Staab, 2020).

COVID-19 ile mücadele için alınmaya çalışılan önlemler aslında sosyal yardımların enformel işçilere de tanınması noktasındaki çabaları (evrenselliği sağlama yollarından birisi) ortaya çıkarmaktadır. Hem sosyal korumanın enformel çalışanlara doğru genişletilmesine hem de kapsamlı sosyal koruma sistemlerine sahip olmak adına ülkedeki sosyal sigorta ve sosyal yardım sistemleri arasında ihtiyaç duyulan bağlantının kurulmasına da katkıda bulunmaktadır (DFID/GIZ, 2020:4). Bu bağlantının kurulması ile sosyal koruma sistemlerinin evrenselliğini gerçekleştirme yönünde önemli bir adım atılmış olacaktır.

Enformel kesimde çalışanların sosyal koruma planları kapsamına alınmasında başvurulacak araçlar arasında, sosyal yardımların evrensel düzeye taşınması, sosyal sigorta planlarının genişletilmesi, kamu hizmetlerine erişimin ve kalitesinin iyileştirilmesi, kentleşme politikalarının (özellikle kent sağlı̆̆ını korumak adına yapılanlar) sosyal koruma sistemlerine göre şekillendirilmesi yer almaktadır (WIEGO, 2019:6-8). Tüm bu faktörlerle birlikte değerlendirildiğinde, sosyal korumanın dışında kalan enformel kesimin kapsanmasının çok boyutlu bir süreci içerdiği ve pandeminin ortaya çıkardığı acil çözümler içerisinde bir öncelik oluşturduğu görülmektedir.

COVID-19 ile mücadelede sosyal koruma sistemlerinin kullanılması düşünülürken, kısa vadeli ve uzun vadeli amaçlarla hareket edilmesi mümkündür. Kısa vadede, hedefleme yapısının uygunluk kriterleri, mali alan, sağlanacak desteklerin türü, hedeflemenin uygulanması v.b. konularla ilgilenilir. Uzun vadede ise, bu sistemlerin tamamlayıcılık özelliğine, zamanlamasına, finanse edilme ve sürdürülebilirliğine ilişkin endişelere odaklanıldığı görülmektedir (DFID/GIZ, 2020:5-7). Bu bağlamda, kısa vadede düşük ve orta gelirli ülkelerin sosyal koruma ve işgücü ile ilişkili önlemleri tatmin edici kabul edilse de orta ve uzun vadede bu ülkelerin sosyal koruma ve işgücü piyasalarının parçalı yapısını düzenlemeleri bir gereklilik olarak ortaya çıkmaktadır (Rutkowski, 2020). 
Tablo 4: COVID-19 öncesi enformel çalışanların sisteme içerilmesi örnekleri

\begin{tabular}{|c|c|c|}
\hline & Sosyal sigorta (katkılı) & Sosyal yardım (katkısız) \\
\hline $\begin{array}{l}\text { Kapsanma/ma } \\
\text { durumu }\end{array}$ & $\begin{array}{l}\text { Düşük ya da hiç katkı kapasitesi } \\
\text { olmayan enformel işçileri kapsam } \\
\text { dışında bırakır. Kapsam içinde yer } \\
\text { aldıklarında da cinsiyete dayalı riskler } \\
\text { (annelik v.b.) dışarıda bırakılır. }\end{array}$ & $\begin{array}{c}\text { Yoksulluk çizgisinin altında } \\
\text { kalmayanlar ve çalışma yaşındaki } \\
\text { enformel işçiler, kapsam dışında } \\
\text { bırakılır. }\end{array}$ \\
\hline $\begin{array}{l}\text { COVID-19 } \\
\text { öncesinde, sosyal } \\
\text { koruma sistemine } \\
\text { enformel } \\
\text { çalışanların dahil } \\
\text { edilmesine yönelik } \\
\text { devletin çabaları }\end{array}$ & $\begin{array}{l}\text { *(Zorunlu ya da gönüllü) katkılı sosyal } \\
\text { sigorta planlarının genişletilmesi } \\
\text { *Sosyal sigorta ödemeleri ile } \\
\text { birleştirilen basitleştirilmiş vergi } \\
\text { rejimleri (Monotax gibi) }\end{array}$ & $\begin{array}{l}\text { *Yaşam döngüsüne ait (çocukluluk, } \\
\text { yaşlılık v.b.) tüm riskleri } \\
\text { hedefleyen nakit transferler } \\
\text { *Kırsalda yoksullukla mücadeleyi } \\
\text { hedefleyen programlar (açıkça gelir } \\
\text { kazanan ya da sağlıklı bireyleri } \\
\text { dışarıda bırakmaz) }\end{array}$ \\
\hline
\end{tabular}

Kaynak: DFID/GIZ, 2020:4

22 Mayıs itibarıyla küresel ölçekte 190 ülkenin COVID-19'a karşı sosyal koruma önlemlerini uygulamaya başladığı ya da benimsediği görülmektedir. 20 Mart ile yani pandemiye karşı alınan ilk önlemler döneminde bunu benimseyen ülke sayısı 45 iken, pandemi yayılırken artış gösterdiği görülmektedir. Sosyal koruma önlemleri üç şekilde uygulanmaktadır: Sosyal kapsamının genişletilmesi, yapılan ödemelerin artırılması, idari gereksinimlerin kolaylaştırılması ve daha kullanıc1 dostu hale getirilmesi (Gentillini vd., 2020).

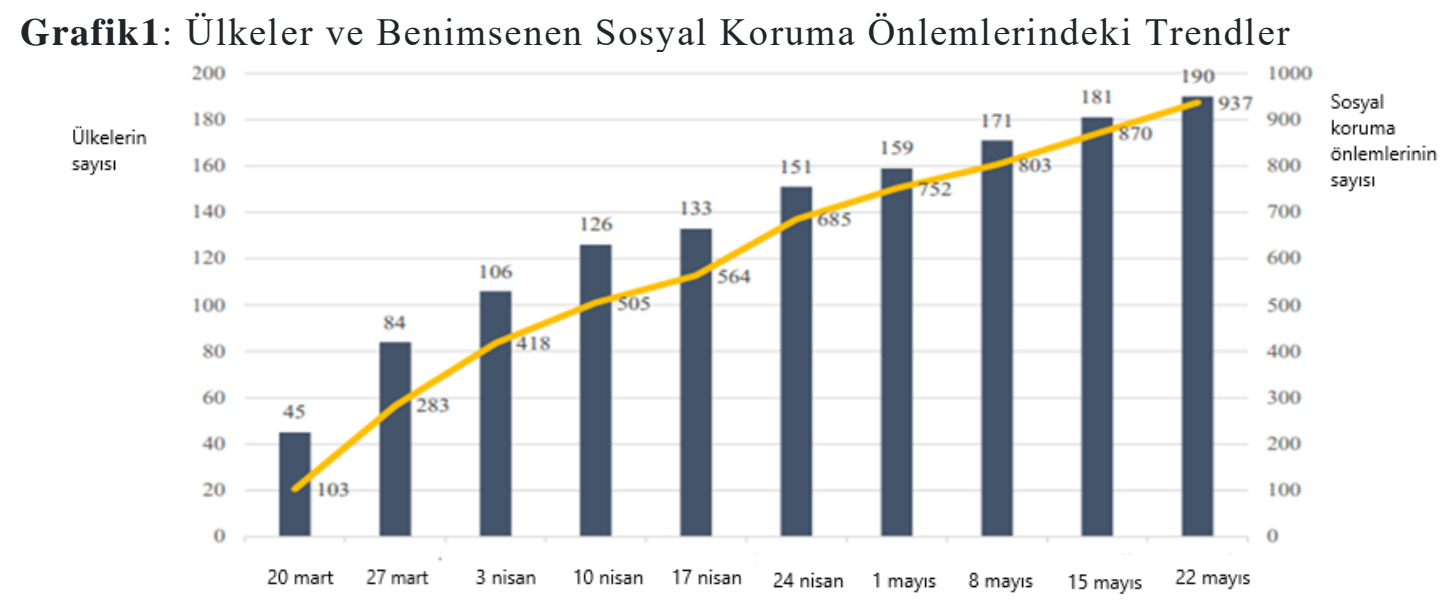

Kaynak: Gentillini vd.(2020:2).

Enformel istihdamın yaygınlığı göz önüne alındığında geliri ikame edecek nakit destekler ya da daha kapsamlı bir ifade ile sosyal koruma önlemleri uygulanmalıdır. Yoksullara ya da çok yoksullara odaklanma yönünde bir eğilim olsa da enformel kesimde çalışanların çoğu bazen bu kategorilere bile dahil olamamaktadır. Bu nedenle, sosyal korumaya ilişkin önlemler evrensel olmalı ya da hedef grup olarak en kırılganları seçmelidir. İkincisi, acil müdahale gerektiren bu durum 
işveren destekli sosyal güvenlik katkılarında bir azalma yaratmanın gerekçesi olmamalıdır. Ayrıca, sosyal koruma önlemleri sağlık, hijyen, bakım v.b. başka alanlardaki önlemlerle bütüncül bir şekilde uygulanmalıdır (Alfers, 2020).

Karantina, sokağa çıkma yasakları ya da sosyal mesafe kuralları düşünüldüğünde temel endüstriler dışında kalan enformel kesim çalışanları neredeyse hiç gelir elde edememektedir. Bunu ağırlaştıran diğer koşullar ise, mal ve hizmet talebindeki düşüşler, girdi maliyetinde artışlar, piyasalara erişilememesi ve bakım faaliyetlerinin artan yüküdür. Bu kesimin yoksulluğa, derin bir yoksulluğa ve/veya gida güvencesizliğine düşmesine yol açması ile COVID-19 enformel kesime yönelik önemli bir müdahale alanı olarak ortaya çıkmaktadır (DFID/GIZ, 2020).

COVID-19 ile mücadelede sıklıkla bahsedilen araçlardan birisi de sosyal güvence ağları ve sosyal koruma sistemlerine başvurulması olmaktadır. Sosyal koruma politikalarının ve araçlarının bu alandaki üstünlükleri belirtilecek olursa: a) kriz anında sağlık, beşerî sermaye, gıda güvencesi v.b. alanlara yönelik koruma sunabilmesi, b) gerçekleştirilen transferlerin ekonomik iyileşmeyi desteklemesi, c) sosyal güvence ağları pek çok ülkede mevcut olduğundan, bu sosyal güvence ağ altyapısı üzerinden programların hedeflerini ve kapsamlarını genişletebilme ya da yenileyebilmenin mümkün olmasıdır (Gilligan, 2020).

GOÜ'lere COVID-19 ile mücadelede, sosyal sigorta sistemini genişletmeleri, mevcut sosyal destek programlarını kullanmaları, sosyal destek ve sosyal sigorta programlarının kapsayamadığı kişilere ulaşabilmek adına yerel hükümetleri ve STK'ları bu sürece dahil etmeleri tavsiye edilmektedir (Gerard v.d, 2020). Ayrıca, hanehalkı genelini düşünüp; birey ve hanehalkı düzeyinde enformelliğin de hesaba katılması gerekmektedir (Gerdin ve Kolev, 2020).

Tablo 5: Sosyal Yardım Programları Genel Değerlendirme (22 Mayıs 2020)

\begin{tabular}{|l|l|l|}
\hline Sosyal yardım program türleri & Alınan önlem sayıs1 & Uygulayan ülke sayıs1 \\
\hline Nakit transferler (koşullu ve koşulsuz) & 246 & 124 \\
\hline Evrensel-tek nakit destek & 5 & 5 \\
\hline Çocuk bakım destekleri & 9 & 9 \\
\hline Emeklilik ödemeleri & 23 & 19 \\
\hline Ayni gida/kupon planları & 103 & 77 \\
\hline Okul beslenme programları & 27 & 22 \\
\hline Finansal yükümlülük desteği(feragat/erteleme) & 134 & 81 \\
\hline İș karşıllı̆ı ücret destekleri & 12 & 9 \\
\hline Toplam sosyal yardım önlemleri & 559 & 168 \\
\hline
\end{tabular}

Kaynak: Gentillini v.d, 2020.

Mart ayının sonu ile 84 ülke, pandemiye cevap olarak sosyal koruma sistemlerinde değișime giderken; 58 ülke de nakit şekildeki transferlerini yeniden düzenlemeyi tercih etmektedir. Hanehalk1 ve küçük işletmelere doğrudan transferler yapılması onlar için gelir ve istihdam kaybını telafi edici etki ortaya çıkarmıştır. Rutkowski vd. (2020)'ye göre, gelişmiş "devletten bireye ödeme" (G2P) sistemine sahip ülkeler transferleri ve nakit destekleri çok hızlı bir şekilde ödeyebilmektedir. Bununla birlikte, ödemelerin dijitalleşmesi kırılgan grupların (merkezden uzakta yaşayanlar, yaşlılar ve engelliler) dışarıda bırakılmasına neden olmamalıdır. Devletten bireye dijital ödeme sistemleri (G2P); devletin doğrudan maliyetlerini azaltıcı, rüşvet ve yolsuzlukları azaltıcı, alıcıların sisteme olan güvenini ve finansal içerilmeyi arttırıcı etkiye sahiptir. Hem kısa hem de uzun vadeli katkıları olan, inovatif bir yöntem olarak yaygınlaşmaktadır. Devletten bireye dijital ortamda yapılan bu ödeme; pandemi nedeniyle sosyal mesafeye uyabilmeyi, yüzyüze gelmekten kaçınmayı da destekleyici bir uygulamadır (Palacios, 2019).

Transferlerin mobil ödeme sistemleri ile yapılabilmesi yoksullara ulaşmada, coğrafi olarak hedeflenmiş nakit transferler düzenleyebilme olanağı sunması ile de ön plana çıkar (Dercon, 2020). 
Dijital ödeme kapasitelerinin genişlemesi ile hükümetler sosyal refah ödemelerini doğrudan bu ödemelerden yararlanan kişilerin hesaplarına aktarabilmektedir (Baur-Yazbeck v.d, 2019). Bu desteklerden faydalanan kişilerin nasıl belirleneceği ve sisteme kaydedileceği, zamanında ve güvenli bir şekilde bu ödemelerin nasıl yapılacağ 1 ve bütçede bu ödemelerin nasıl gösterilip raporlanacağı şeklinde bazı meydan okumalarla karşılaşılacaktır (IMF, 2020b). COVID-19'a karşı ilk dalga uygulamalar içerisinde yapılan nakit transferlere bakıldığında, bu ödemelerin dijitalleştirilmesinin ve dijital ödeme ekosisteminin geliştirilmesinin ne kadar önemli olduğu görülmektedir (Gentillini vd., 2020, 15).

COVID-19 ile mücadelede GOÜ ve GÜ benzer sorunlarla karşı karşıya olsa da kaynaklar ve harcama kapasitesi açısından gelişmiş ülkeler daha avantajlı durumdadır. Temel olarak, üç alanda politika önerileri ile karşılaşılmaktadır. İlki toplum sağlığının sağlanması, ikincisi özellikle aşılar aracılığıyla çıkış stratejilerine yatırım yapılması ve üçüncüsü de ekonomik alanda iyileşmeye yönelik yatırım yapılmasıdır. Bu üçüncü ekonomik alan, aslında resesyonun etkilerini olabildiği kadar az kılmak anlamındadır. Yoksulluk ve GSYH ilişkili olduğundan ${ }^{3}$ yoksullar ve yoksul ülkelerde ekonomik olarak kırılgan olanlar için durum daha da risklidir. Bu nedenle, yoksulların nakit destekler alabilmesi önemlidir. Enformel ya da kendi adına çalışanlar sadece şu an gelir/ iş kaybı yaşamakla kalmadığı gibi ayrıca kalıcı olarak da yoksulluğa düşmektedir (Dercon, 2020). Yoksulluğun ulaşabileceği bu düzey ve boyut yine ülkelerin sosyo-ekonomik performansları üzerinde uzun vadeye de yayılabilecek sorunların kaynağını oluşturacaktır.

\section{Sonuç ve Öneriler}

Pandemi döneminde finansal, mali ve sağlık alanlarında alınabilecek önlemler kadar sosyal koruma sistemlerine ilişkin düzenlemeler ve esnekliklerle de karşılaşılmaktadır. Sosyal destekler ve yardımlar alanında, koşulluluk ilkesinin geçici olarak kaldırılması tercih edildiğinde, desteklerin ihtiyaç sahiplerine daha hızlı ulaştırılması sağlanabilir. Bu anlamda, esneklik sağlayacak her türlü düzenleme pandemi ile mücadele sırasında uygulamaya konulabilir. Tüm bu esneklikler kazandırılırken unutulmaması gereken nokta, bu desteklerin uzun süre devam etmesi halinde mali anlamda önemli bir yük oluşturacaklarıdır. Bir de bu desteklerden yeni faydalanacak kişilerin tespitinde, adayların yüzyüze değerlendirilmesi, kişisel görüşmelerin yapılması v.b yöntemler tercih edilirse, virüsün yayılım riski artacaktır (Gilligan, 2020).

Hem GOÜ hem de GÜ’lerde değişen çalışma biçimleri düşünüldüğünde, standart istihdam ilişkilerinden farklılaşan bir dönemde olunduğu göz önüne alındığında birey ve hanehalkına karşılaştıkları şokların üstesinden gelebilmek için bir dizi kurum, düzenleme, müdahale ile ifade edilebilecek risk paylaşım politikaları ile destek verilmesi tercih edilebilir. Bu politikalara özellikle işgücü piyasasındaki etkileşimi (işçinin korunması, işgücü piyasası kurumları) düzenleyen resmî kurallar ve yapılar, riskleri azaltacak araçlar (sosyal güvenlik ve sosyal yardım) da dahildir. COVID19 bu alanların hepsi üzerinde etkilidir (Packard vd., 2019:2).

ILO standartlarına göre COVID-19 ile mücadelede ülkelerin benimsemesi gereken dört temel strateji şöyledir: İstihdam ve ekonominin canlandırılması, işletmelerin, işlerin ve gelirlerin desteklenmesi, iş yerinde çalışanların korunması ve çözüme yönelik sosyal diyaloğun oluşturulması (ILO, 2020e:8). İşücü piyasası sorunlarından etkilenen bölgelere, sektörlere ya da mesleklere özgü olan politikaların uygulanması tercih edilmelidir. İstihdam alanındaki kırılganlıklar göz önünde bulundurularak, hedeflenmiş nakit transfer programları ve sosyal güvence ağları oluşturulmalıdır (Sanchez vd., 2020:7).

COVID-19 varlığında politika yapıcılı̆̆ yüksek belirsizlik içerdiğinden, verilen kararlar ya çok az bilgi ile ya da hiçbir bilgi olmadan alındığı için hatalara açıktır. Bu belirsizlik ortamı siyasiler

${ }^{3}$ Literatürde bu ilişkiyi açıklayan çok fazla çalışma bulunmaktadır. (Bkz: Grunewald, 2006; Adams, 2003; Vijayakumar, 2013)

www.turkishstudies.net/turkishstudies 
ve karar alıcılar için doğaçlama ya da ani şekilde hareket etmek anlamını da taşır (Dercon, 2020). COVID-19 ortamında politika uygulamayı zorlaştıran durumlardan birisi de politikacılar için seçimlere katılma ve kazanma gibi bir durumun varlığıdır. Bu nedenle, pandemi ile mücadele ya da pandemiye hazırlık gibi uzun vadede realize olacak politikalar için para harcamak, düzenleme yapmak pek çok toplumda kolaylıkla gerçekleştirilememektedir (Frieden, 2020:8).

COVID-19, devletin ve kurumların kapasitelerine yönelik önemli bir meydan okuma ortaya çıkarmıştır. Virüsün yayılmasını önlemeye yönelik devletlerin gösterdiği çabalar etkin ve kapsayıcı bir yönetişimin, devlet ve vatandaş arasındaki ilişkinin önemini göstermektedir (Kauzya, 2020:2). COVID-19 ile mücadele devletlerin işlevinin de tartışılmasına neden olmaktadır (Cebeci, 2020). Bu bağlamda, COVID-19'dan çıkış stratejisi olarak ulusal düzeyde izlenecek politikalar, etkileri ve sonuçları açısından devlet ve birey arasındaki ilişkinin yeniden yapılanmasına yönelik talepleri de ortaya çıkarabilecektir.

Uluslararası düzlemde, kriz ile ortaya çıkan sorunların çözümünde izlenecek yola bakıldığında, COVID-19 sonrası küresel düzenin işleyişinde, a) kamu sağlığı alanında bilimsel temelli uluslararası iş birliğine gidilmesi, b) çalışma, arz, teslim süreçlerinde teknolojinin merkezi konuma geçmesi, c) doğal olaylarının varlığının (iklim değişikliği, salgınlar, küresel ısınma) hatırlanması ve bu tür olaylar karşısında uzun dönem dayanıklılığın tesis edilmesi (Dabla-Norris vd., 2020:25) gibi daha uzun vadeli ve küresel iş birliğini gerektiren alanların ön plana çıkacağı tahmin edilmektedir.

COVID-19 tüm toplumları, mevcut küresel düzenin işleyişini etkileyen ve yeniden şekillendiren bir sürecin içerisinde bırakmıştır. Öncelikli amaç virüsün daha fazla sayıda kişiye yayılmasını önlemek olduğundan sokağa çıkma yasakları, okulların ve kreşlerin tatil edilmesi, karantina v.b uygulamalarla kamu sağlığı korunmaya çalışılmıştır. Tüm bu ve benzeri uygulamaların ilk etkisi ekonomik anlamda özellikle de işgücü piyasaları üzerinde görülmektedir. İstihdam düzeyinde düşme ve bununla birlikte sosyal güvence ağına dahil olamadığı için yaşamını sürdürme noktasında ciddi sorunlarla karşılaşan bireyler yoksulluk ile de mücadele etmek zorunda kalmaktadır.

İşgücü piyasaları değerlendirilirken, COVID-19'dan en çok etkilenen kesim ev temelli çalışanlar ve enformel kesimde istihdam edilmiş olanlardır. Pandeminin ilk günlerinden başlayarak şu ana kadar gelen süreçte, bu kesimlere daha fazla ulaşabilmek adına ülkelerin sosyal koruma planlarını genişlettikleri ve kapsamını derinleştirdikleri görülmektedir. Yaşam boyu karşılaşılabilecek risklerden biri olarak COVID-19, devletlerin başta sağlik olmak üzere ekonomik ve sosyal anlamda vatandaşlarına böylesi bir krizden çıkmalarını sağlayacak her türlü güvence ve desteği vermeleri gerektiğinin bir kanıtı olarak, 21. yüzyılda pandemi ile mücadelenin bir gerçeği olarak karşımızdadır.

\section{Kaynakça}

Adams, R.H., Jr. (2003). Economic growth, inequality, and poverty: findings from a new data set. Policy Research Working Paper No:2972. World Bank, Washington, DC. https://openknowledge.worldbank.org/handle/10986/19109

Alfers, L. (2020). Pandemic: informal workers urgently need income replacement - and more protections. 23 Mart 2020, WIEGO Blog, https://www.wiego.org/blog/pandemic-informalworkers-urgently-need-income-replacement-and-more-protections, (Erişim 01.04.2020).

Alfers, L., Moussié, R., \& Harvey, J. (2020). The COVID-19 crisis: income support to informal workers is necessary and possible. OECD Development Matters, 22 April 2020, https://oecddevelopment-matters.org/2020/04/22/the-covid-19-crisis-income-support-to-informalworkers-is-necessary-and-possible/, (Erişim 03.06.2020). 
Bartik, A.W., Bertrand, M., Cullen, Z.B., Glaeser, E.L., Luca, M. \& Stanton, C.T. (2020). How are small businesses adjusting to Covid-19? Early Evidence From a Survey, NBER Working Papers, No:26989, http://www.nber.org/papers/w26989.

Baur-Yazbeck, S., Chen, G., \& Roest, J. (2019). The future of G2P payments: expanding customer choice. Focus Note. Washington, D.C.: CGAP.

Berg., J., Bonnet, F.\& Soares, S. (2020). Working from home: estimating the worldwide potential, 11 May 2020, VOX: CEPR Policy Portal, https://voxeu.org/article/working-homeestimating-worldwide-potential, (Erişim 13.05.2020).

Carr, M., Chen, M.A.\& Tate, Jane. (2020). Globalization and home-based workers, Feminist Economics, 6(3): 123-142.

Cebeci, A. (2020). Kapitalist toplumsal ilişkilerde dönüşüm: dönüşümün katalizörü olarak salgın. Turkish Studies, 15(4), 1409-1428. https://dx.doi.org/10.29228/TurkishStudies.44872

CISA (2020). Advisory memorandum on identification of essential critical infrastructure workers $\begin{array}{lllll}\text { during } & \text { Covid-19 } & \text { response. } & 19 & \text { May1s }\end{array}$ https://www.cisa.gov/sites/default/files/publications/Version_3.1_CISA_Guidance_on_Ess ential_Critical_Infrastructure_Workers_0.pdf, (Erişim tarihi 24.06.2020).

Dabla-Norris, E., Vitor G. \& Kochhar K. (2020). Preparing for an unknown world, IMF Finance and Development, June 2020, 57(2):24-25.

Dabla-Norris, E.\& ve Zdzienicka, A. (2020). The Devil is in the Details. IMF Finance and Development, June 2020, 57(2):37-39.

Dell'Ariccia G., Paolo. M., Spilimbergo, A. \& Zettelmeyer, J.(2020). Economic Policies for the COVID-19 War. IMF Blog, 1 Nisan 2020, https://blogs.imf.org/2020/04/01/economicpolicies-for-the-covid-19-war/, (Erişim 11.05.2020)

Dercon, S. (2020). No-Regret policies for the COVID-19 crisis in developing countries. Center for Global Development Notes,17 Nisan 2020, https://www.cgdev.org/publication/no-regretpolicies-covid-19-crisis-developing-countries, (Erişim:01.05.2020).

DFID/ GIZ (2020). Informal workers and social protection. SPACE-Social Protection Approaches to COVID-19: Expert advice May 2020, https://socialprotection.org/sites/default/files/publications_files/SPACE_Informal\%20Wor kers_V1.pdf, (Erişim 01.06.2020).

Dingel, J.I. \& Neiman, B. (2020). How many jobs can be done at home?, Brecker Friedman Institute White Paper, June 2020.

European Commission (2020). Policy measures taken against the spread and impact of the $\begin{array}{lllll}\text { coronavirus } & - & 14 & \text { April } & 2020 .\end{array}$ https://ec.europa.eu/info/sites/info/files/policy_measures_taken_against_the_spread_and_i mpact_of_the_coronavirus_14042020.pdf, (Erişim tarihi 12.05.2020)

Farole, T., Goga, S.\& Ionescu-Heroui, M. (2020). Rethinking lagging regions: using cohesion policy to deliver on the potential of Europe's regions. The World Bank: Washington DC.

Florini, A.\& Sharma, S. (2020). Reckoning with systemic hazards. IMF Finance and Development, June 2020, Vol:57(2):48-51.

Frieden, J. (2020). The Political Economy of Economic Policy. IMF Finance and Development, June 2020, Vol:57(2):5-9. 
García, A.B. \& Gruat, J.V. (2003). Social Protection: A Life cycle continuum investment for social justice, poverty reduction and sustainable development. ILO, Geneva.

Gentilini, U., Almenfi, M., Dale, P., Blomquist, J., Natarajan, H., Galicia, G., Palacios, R.\& Desai, V. (2020). Social protection and jobs responses to COVID-19: A real-time review of Country measures "Living paper" version 10, 22 Mayis 2020, https://www.ugogentilini.net/wpcontent/uploads/2020/05/Country-SP-COVID-responses_May22.pdf, (Erişim 25.05.2020).

Georgieva, K. (2020). Beyond the Crisis. Policies, Politics and Pandemics, IMF Finance and Development, June 2020,57(2):10-11.

Gerard, F., Imbert, C. \& Orkin, K. (2020). Social Protection Response to the COVID-19 Crisis: Options for Developing Countries. Economics for Inclusive Prosperity Brief. https://econfip.org/policy-brief/social-protection-response-to-the-covid-19-crisis-optionsfor-developing-countries/, (Erişim: 12.05.2020).

Gerdin, A. \& Kolev, A. (2020). Why protecting informal economy workers is so critical in time of COVID-19. OECD Development Matters, 17 Nisan 2020, https://oecd-developmentmatters.org/2020/04/17/why-protecting-informal-economy-workers-is-so-critical-in-timeof-covid-19/, (Erişim 02.05.2020)

Gilligan, D. (2020). Social safety nets are crucial to the COVID-19 response. Some lessons to boost their effectiveness. 18 June 2020, IFRI Blog Post, https://www.ifpri.org/blog/social-safetynets-are-crucial-covid-19-response-some-lessons-boost-their-effectiveness, 20.06.2020)

Glover, A., Heathcote, J., Krueger, D. \& Ríos-Rull, J.V. (2020) Health versus wealth: On the distributional effects of controlling a pandemic. Federal Reserve Bank of Kansas City, Research Working Paper No:20-03, May1s 2020, https://doi.org/10.18651/RWP2020-03

Gottlieb, C., Grobovsek, J. \& Poschke, M. (2020). Working from home across countries. https://markus-poschke.research.mcgill.ca/papers/GGP_WFH.pdf, (Erişim 01.06.2020).

Grunewald, R. (2006). The connection between poverty and the economy. 1 Kasim 2006, Federal Reserve Bank of Minneapolis, https://www.minneapolisfed.org/article/2006/the-connectionbetween-poverty-and-the-economy, (Erişim tarihi 01.04.2020).

Hatayama, M., Viollaz., M. \& Winkler, H. (2020a). Jobs' amenability to working from home evidence from skills surveys for 53 Countries. World Bank Group: Social Protection and Jobs Global Practice, May 2020, Policy Research Working Paper, No:9241.

Hatayama., M, Viollaz., M.\& Winkler, H. (2020b). Who can really work from home? World Bank Blogs, 28 Mayis 2020, https://blogs.worldbank.org/jobs/who-can-really-work-home, (Erişim tarihi 01.06.2020)

ILO (2020a). Social protection responses to the COVID-19 pandemic in developing countries: Strengthening resilience by building universal social protection, ILO Brief, Mayis 2020, https://www.social-protection.org/gimi/RessourcePDF.action?id=56542,

(Erişim 01.06.2020).

ILO (2020b). COVID-19 and the world of work: Impact and policy responses. ILO Monitor 1st Edition, 18 Mart 2020, https://www.ilo.org/wcmsp5/groups/public/---dgreports/--dcomm/documents/briefingnote/wcms_738753.pdf, (Erişim tarihi 01.04.2020).

ILO (2020c). Livelihoods of more than 55 million domestic workers at risk due to COVID-19. 16 June 2020, https://www.ilo.org/global/about-the-ilo/newsroom/news/WCMS_748093/lang-en/index.htm, (Erişim 17. 06.2020). 
ILO (2020d). Impact of the COVID-19 crisis on loss of jobs and hours among domestic workers. 15 June 2020, https://www.ilo.org/wcmsp5/groups/public/---ed_protect/---protrav/--travail/documents/publication/wcms_747961.pdf, (Erişim tarihi 20.06.2020)

ILO (2020e). ILO Monitor: COVID-19 and the world of work. Second edition Updated estimates and analysis. 16 Nisan 2020, https://www.ilo.org/wcmsp5/groups/public/---dgreports/--dcomm/documents/briefingnote/wcms_740877.pdf, (Erişim 05.06.2020).

ILO (2018). Women and Men in The Informal Economy: A Statistical Picture (third edition) / International Labour Office, Geneva: ILO.

ILO (2015a). Home-based workers: Decent work and social protection through organization and empowerment, Experiences, good practices and lessons from home-based workers and their organizations, International Labour Office - Jakarta: ILO, 2015

ILO (2015b). International Labour Conference: Recommendation 204, https://www.ilo.org/wcmsp5/groups/public/---ed_norm/---

relconf/documents/meetingdocument/wcms_377774.pdf, (Erişim 01.06.2020).

ILO (2014). Transitioning from the informal to the formal economy, Fifth Item on the Agenda, International Labour Conference, 103rd Session, https://www.ilo.org/wcmsp5/groups/public/---ed_norm/--relconf/documents/meetingdocument/wcms_218128.pdf, (Erişim 01.04.2020).

ILO (1996), C177-Home Work Convention, 1996 (No. 177) https://www.ilo.org/dyn/normlex/en/f?p=NORMLEXPUB:12100:0::NO::P12100_INSTR UMENT_ID:312322, (Erişim: 03.04.2020).

IMF (2020a). World economic outlook update, June 2020. https://www.imf.org/en/Publications/WEO/Issues/2020/06/24/WEOUpdateJune2020, (Erişim tarihi 25.06.2020).

IMF (2020b). Digital solutions for direct cash transfers in emergencies. IMF Fiscal Affairs, https://www.findevgateway.org/sites/default/files/users/user331/en-special-series-on-covid19-digital-solutions-for-direct-cash-transfers-in-emergencies.pdf, (Erişim 03.06.2020).

IPC-IG/GIZ/BMZ/DFAT (2020). Social protection financing in the wake of COVID-19 and beyond. 5 Mayis 2020, https://socialprotection.org/social-protection-financing-wake-covid-19-andbeyond, (Erişim 01.06.2020).

Kamal, R., McDermott, D. \& Cox, C. (2019). How has U.S. spending on healthcare changed over time? Petersen-KFF Health System Tracker, 20 Aralı 2019, https://www.healthsystemtracker.org/chart-collection/u-s-spending-healthcare-changedtime/\#item-start, (Erişim tarihi 12.05.2020).

Kauzya, J.M.(2020). COVID-19: Reaffirming state-people governance relationships. United Nations Department of Economic and Social Affairs, Policy Brief No:75, Mayıs 2020, https://www.un.org/development/desa/dpad/wpcontent/uploads/sites/45/publication/PB_75.pdf, (Erişim 01.06.2020).

Köse, M. A., Nagle, P., Ohnsorge, F. \& Sugawara, N. (2020a). Global Waves of debt: causes and consequences. Washington, DC: World Bank.

Köse, M.A., Ohnsorge, F., Nagle, P. \& Sugawara, N. (2020b). Caught by a Cresting Debt Wave. IMF Finance and Development, (24-25), June 2020, 57(2):24-25. 
McKibbin, W. \& Fernando, R. (2020). The global macroeconomic impacts of COVID-19: seven scenarios. 2 Mart 2020, Brookings Institute Report, https://www.brookings.edu/wpcontent/uploads/2020/03/20200302_COVID19.pdf, (erişim tarihi 12.05.2020).

Minter, A. (2020). In the informal economy, there's no shelter from the virus, 3 Nisan 2020, BloombergOpinion, https://www.bloombergquint.com/global-economics/in-the-informaleconomy-there-s-no-shelter-from-the-virus, (Erişim tarihi 10.05.2020).

Mongey, S., Pilossoph, L.\&Weinberg, A. (2020). Which workers bear the burden of social distancing policies? NBER Working Paper Series, No: 27085, http://www.nber.org/papers/w27085,

Moussié, R.\& Staab, S. (2020). Three ways to contain COVID-19's impact on informal women workers, 18 Mayis 2020, https://data.unwomen.org/features/three-ways-contain-covid-19simpact-informal-women-workers, (erişim 01.06.2020)

OECD (2020). Government support and the COVID-19 pandemic. https://read.oecdilibrary.org/view/?ref=128_128572-w5qyf5699d\&title=Government-support-and-theCOVID-19-pandemic, (Erişim tarihi 21.05.2020).

Ortiz, I. (2018). The case for universal social protection: everyone faces vulnerabilities during their lifetime, IMF Finance and Development, 55(4):32-34.

Packard, T., Gentilini, U., Grosh, M., O’Keefe, P., Palacios, R., Robalino, D. \& Santos, I.(2019). Protecting all: risk sharing for a diverse and diversifying world of work. Human Development Perspectives. Washington, DC: World Bank. doi: 10.1596/978-1-4648-14273

Palacios, R. (2020). G2P Payments for social protection. Presentation in Hot Topics in Social Protection, 28 Ekim 2019, Washington DC. http://pubdocs.worldbank.org/en/908331572357042931/SPJCC19-D1-S4-PalaciosG2P.pdf, (Erişim 05.05.2020).

Rae, M., Claxton, G., Kurani, N., McDermott, D.\& Cox, C. (2020). Potential costs of COVID-19 treatment for people with employer coverage. Petersen-KFF Health System Tracker, 13 Mart 2020, https://www.healthsystemtracker.org/brief/potential-costs-of-coronavirus-treatmentfor-people-with-employer-coverage/, (Erişim tarihi 21.05.2020).

Rutkowski, M. (2020). COVID-19 reinforces the case for fundamental reform of our social protection systems. World Bank Blogs. 1 Mayis 2020, https://blogs.worldbank.org/jobs/covid-19-reinforces-case-fundamental-reform-our-socialprotection-systems, (erişim 01.06.2020).

Rutkowski, M., Mora, A.G., Bull, G.L., Guermazi, B., \& Grown, C. (2020). Responding to crisis with digital payments for social protection: short-term measures with long-term benefits, 31 Mart 2020, https://blogs.worldbank.org/voices/responding-crisis-digital-payments-socialprotection-short-term-measures-long-term-benefits, (erişim 01.05.2020).

Saltiel F. (2020). Who can work from home in developing countries? http://econweb.umd.edu/ saltiel/files/wfh_mostrecent.pdf, (Erişim tarihi 01.05.2020).

Sanchez., D.G., Parra, N.G., Ozden, C. \& Rijkers, B. (2020). Which Jobs Are Most Vulnerable to COVID-19? What an Analysis of the European Union Reveals, World Bank Group, Policy and Research Brief, No:34, http://documents.worldbank.org/curated/en/820351589209840894/Which-Jobs-Are-MostVulnerable-to-COVID-19-What-an-Analysis-of-the-European-Union-Reveals. 
Shibata, I. (2020). The Distributional impact of recessions: the global financial crisis and the pandemic recession. IMF Working Paper, WP/20/96.

Sumner, A., Hoy, C.\& Ortiz-Juarez, E. (2020). Estimates of the impact of COVID-19 on global poverty. UNU-WIDER Working Paper No: 2020/43, https://doi.org/10.35188/UNUWIDER/2020/800-9.

The CARES Act Works for All Americans. https://home.treasury.gov/policy-issues/cares, (erişim 04.06.2020)

Tomer, A.\& Kane, J.W. (2020). "How to protect essential workers during COVID19," Brookings Institute Report, 31 Mart 2020. https://www.brookings.edu/research/how-to-protectessential-workers-during-covid-19/, (Erişim tarihi 11.05.2020).

Ulrichs, M. \& White-Kaba, M. (2019). A systems perspective on universal social protection-towards life-long equitable access to comprehensive social protection for all. Federal Ministry for Economic Cooperation and Development (BMZ). January 2019, http://health.bmz.de/ghpc/discussion_papers/Universal_Social_Protection/index.html, (Erișim tarihi 02.04.2020).

Vijayakumar, S. (2013). An empirical study on the nexus of poverty, GDP growth, dependency ratio and employment in developing countries. 5(2):67-82, DOI: 10.7441/joc.2013.02.05

WIEGO (2019). Extending social protection to informal workers, Briefing Note, Mart 2019, https://www.wiego.org/sites/default/files/publications/files/Social\%20Protection\%20Infor mal\%20Workers\%20for\%20web_0.pdf, (Erişim 01.04.2020).

WIEGO (2020a). Home-Based workers. https://www.wiego.org/informal-economy/occupationalgroups/home-based-workers, (Erişim tarihi 11.05.2020).

WIEGO (2020b). Home-based workers face a new kind of isolation, https://www.wiego.org/homebased-workers-face-new-kind-isolation, (Erişim tarihi 12.05.2020). 